\author{
A. Ashyralyev ${ }^{1-3}$, M. Urun ${ }^{1,4}{ }^{*}$ \\ ${ }^{1}$ Near East University, Nicosia, Turkey; \\ ${ }^{2}$ Peoples' Friendship University of Russia (RUDN University), Moscow, Russia; \\ ${ }^{3}$ Institute of Mathematics and Mathematical Modeling, Almaty, Kazakhstan; \\ ${ }^{4}$ Galatasaray University, Istanbul, Turkey \\ (E-mail: allaberen.ashyralyev@neu.edu.tr, murun@gsu.edu.tr)
}

\title{
On the Crank-Nicolson difference scheme for the time-dependent source identification problem
}

\begin{abstract}
In this study the source identification problem for the one-dimensional Schrödinger equation with non-local boundary conditions is considered. A second order of accuracy Crank-Nicolson difference scheme for the numerical solution of the differential problem is presented. Stability estimates are proved for the solution of this difference scheme. Numerical results are given.
\end{abstract}

Keywords: identification problem, Schrödinger equation, difference scheme, Crank-Nicolson, stability.

\section{Introduction}

Source identification problems (SIPs) have the significant role in natural science, applied sciences, engineering, quantum mechanics, diffusion equations, heat equations (see [1-4] and references therein). The theory and applications of SIPs for partial differential equations (PDEs) were studied in many works (see [5-32] and references therein). The time-dependent SIP

$$
\left\{\begin{array}{l}
i \frac{\partial u(t, x)}{\partial t}-\frac{\partial}{\partial x}\left(a(x) \frac{\partial u(t, x)}{\partial x}\right)+\delta u(t, x) \\
=p(t) q(x)+f(t, x), t \in(0, T), x \in(0, l), \\
u(0, x)=\varphi(x), x \in[0, l] \\
u(t, 0)=u(t, l), u_{x}(t, 0)=u_{x}(t, l), \\
\int_{0}^{l} u(t, x) d x=\zeta(t), t \in[0, T]
\end{array}\right.
$$

for the one-dimensional Schrödinger equation (SE) was investigated [33]. Here $0<a \leq a(x), f(t, x), \zeta(t)$, $\varphi(x), q(x)$ and $a(x)$ are given sufficiently smooth functions and $q(0)=q(l), q^{\prime}(0)=q^{\prime}(l)$ and $\int_{0}^{l} q(x) d x \neq 0$. Stability estimates were established for the solution of source identification problem (1). A first order of accuracy difference scheme was investigated for the numerical solution of this problem.

In this paper a second order of accuracy Crank-Nicolson difference scheme for the numerical solution of problem (1) is presented. Stability estimates are proved for the solution of the difference scheme. Numerical results are provided.

\section{Stability of difference problem}

To formulate results on difference problem we introduce the normed space. Let $C_{\tau}(H)=C\left([0, T]_{\tau}, H\right)$ of all mesh functions $\phi^{\tau}=\left\{\phi_{k}\right\}_{k=0}^{N}$ defined on

$$
[0, T]_{\tau}=\left\{t_{k}=k \tau, 0 \leq k \leq N, N \tau=T\right\}
$$

with values in $H$ equipped with the norm

$$
\left\|\phi^{\tau}\right\|_{C_{\tau}(H)}=\max _{0 \leq k \leq N}\left\|\phi_{k}\right\|_{H}
$$

\footnotetext{
${ }^{*}$ Corresponding author.

E-mail: murun@gsu.edu.tr
} 
Moreover, $L_{2 h}=L_{2}[0, l]_{h}$ are normed spaces of all mesh functions $\gamma^{h}(x)=\left\{\gamma_{n}\right\}_{n=0}^{M}$ defined on

$$
[0, l]_{h}=\left\{x_{n}=n h, 0 \leq n \leq M, M h=l\right\}
$$

equipped with the norm

$$
\left\|\gamma^{h}\right\|_{L_{2 h}}=\left\{\sum_{i=0}^{M}\left|\gamma_{i}\right|^{2} h\right\}^{\frac{1}{2}}
$$

and $W_{2 h}^{2}=W_{2}^{2}[0, l]_{h}$ is the Sobolev space with norm

$$
\left\|\gamma^{h}\right\|_{W_{2 h}^{2}}=\left\{\sum_{i=0}^{M}\left|\gamma_{i}\right|^{2} h+\sum_{i=1}^{M-1}\left|\frac{\gamma_{i+1}-2 \gamma_{i}+\gamma_{i-1}}{h^{2}}\right|^{2} h\right\}^{\frac{1}{2}}
$$

To the differential operator $A$ defined by (2) we introduce the difference operator $A^{h}$ defined by the formula

$$
A^{h} \psi^{h}(x)=\left\{-\frac{1}{h}\left(a_{n+1} \frac{\psi_{n+1}-\psi_{n}}{h}-a_{n} \frac{\psi_{n}-\psi_{n-1}}{h}\right)+\delta \psi_{n}\right\}_{n=1}^{M-1}, a_{n}=a\left(x_{n}\right)
$$

acting in the space of grid functions $\psi^{h}(x)=\left\{\psi_{n}\right\}_{n=0}^{M}$ defined on $[0, l]_{h}$ satisfying the conditions $\psi_{M}^{k}=\psi_{0}^{k}$, $\psi_{M}^{k}-\psi_{M-1}^{k}=\psi_{1}^{k}-\psi_{0}^{k}$. For the numerical solution $\left\{u_{n}^{\tau}\right\}_{n=0}^{M}$ of problem (1) we consider the second order of accuracy Crank-Nicolson difference scheme

$$
\left\{\begin{array}{l}
i \frac{u_{n}^{k}-u_{n}^{k-1}}{\tau}-\frac{1}{2 h}\left(a_{n+1} \frac{u_{n+1}^{k}-u_{n}^{k}}{h}-a_{n} \frac{u_{n}^{k}-u_{n-1}^{k}}{h}\right) \\
-\frac{1}{2 h}\left(a_{n+1} \frac{u_{n+1}^{k-1}-u_{n}^{k-1}}{h}-a_{n} \frac{u_{n}^{k-1}-u_{n-1}^{k-1}}{h}\right)+\delta \frac{u_{n}^{k}+u_{n}^{k-1}}{2} \\
=\frac{p_{k}+p_{k-1}}{2} q_{n}+f_{k}\left(x_{n}\right), f_{k}\left(x_{n}\right)=f\left(t_{k}-\frac{\tau}{2}, x_{n}\right), \\
a_{n}=a\left(x_{n}\right), q_{n}=q\left(x_{n}\right), 1 \leq k \leq N, 1 \leq n \leq M-1, \\
u_{n}^{0}=\varphi_{n}, \varphi_{n}=\varphi\left(x_{n}\right), 0 \leq n \leq M \\
u_{M}^{k}=u_{0}^{k}, u_{M}^{k}-u_{M-1}^{k}=u_{1}^{k}-u_{0}^{k}, \sum_{i=1}^{M} u_{i}^{k} h=\zeta_{k}, \\
\zeta_{k}=\zeta\left(t_{k}\right), 0 \leq k \leq N .
\end{array}\right.
$$

Let us give the following result on the stability of DS (3).

Theorem 1. For the solution of DS (3) the stability estimates are satisfied:

$$
\begin{gathered}
\left\|\left\{\frac{1}{\tau}\left(u_{k}^{h}-u_{k-1}^{h}\right)\right\}_{k=1}^{N}\right\|_{C_{\tau}\left(L_{2 h}\right)}+\left\|\left\{\frac{u_{k}^{h}+u_{k-1}^{h}}{2}\right\}_{k=1}^{N}\right\|_{C_{\tau}\left(W_{2 h}^{2}\right)}+\left\|\left\{\frac{p_{k}+p_{k-1}}{2}\right\}_{k=1}^{N}\right\|_{C[0, T]_{\tau}} \\
\leq Q(q)\left[\left\|\varphi^{h}\right\|_{W_{2 h}^{2}}+\left\|f_{1}^{h}\right\|_{L_{2 h}}+\left|\zeta_{0}\right|\right. \\
\left.+\left\|\left\{\frac{1}{\tau}\left(f_{k}^{h}-f_{k-1}^{h}\right)\right\}_{k=2}^{N}\right\|\left\|_{C_{\tau}\left(L_{2 h}\right)}+\right\|\left\{\frac{1}{\tau}\left(\zeta_{k}-\zeta_{k-1}\right)\right\}_{k=1}^{N} \|_{C[0, T]_{\tau}}\right] .
\end{gathered}
$$

Proof. Denote that

$$
u_{n}^{k}=w_{n}^{k}-i \eta_{k} q_{n}
$$

where

$$
\frac{p_{k}+p_{k-1}}{2}=\frac{\eta_{k}-\eta_{k-1}}{\tau}, 1 \leq k \leq N, \eta_{0}=0
$$

and $w_{n}^{k}$ is the solution of the following Crank-Nicolson difference scheme 


$$
\left\{\begin{array}{l}
i \frac{w_{n}^{k}-w_{n}^{k-1}}{\tau}-\frac{1}{2 h}\left(a_{n+1} \frac{w_{n+1}^{k}-w_{n}^{k}}{h}-a_{n} \frac{w_{n}^{k}-w_{n-1}^{k}}{h}\right) \\
-\frac{1}{2 h}\left(a_{n+1} \frac{w_{n+1}^{k-1}-w_{n}^{k-1}}{h}-a_{n} \frac{w_{n}^{k-1}-w_{n-1}^{k-1}}{h}\right)+\delta \frac{w_{n}^{k}+w_{n}^{k-1}}{2} \\
=f_{k}\left(x_{n}\right)-i \frac{\eta_{k}+\eta_{k-1}}{2}\left[-\frac{1}{2 h}\left(a_{n+1} \frac{q_{n+1}-q_{n}}{h}-a_{n} \frac{q_{n}-q_{n-1}}{h}\right)+\delta q_{n}\right] \\
1 \leq k \leq N, 1 \leq n \leq M-1 \\
w_{n}^{0}=\varphi_{n}, 0 \leq n \leq M \\
w_{M}^{k}=w_{0}^{k}, u_{M}^{k}-u_{M-1}^{k}=u_{1}^{k}-u_{0}^{k}, 0 \leq k \leq N
\end{array}\right.
$$

Now, we estimate $\left|\frac{p_{k}+p_{k-1}}{2}\right|$. Using the conditions $\sum_{m=1}^{M} u_{m}^{k} h=\zeta_{k}$ and (4), we obtain

$$
\begin{gathered}
\eta_{k}=\frac{i}{d_{1}}\left(\sum_{m=1}^{M} w_{m}^{k} h-\zeta_{k}\right), d_{1}=\sum_{m=1}^{M} q_{m} h, 1 \leq k \leq N, \\
\frac{p_{k}+p_{k-1}}{2}=\frac{\sum_{m=1}^{M}\left(w_{m}^{k}-w_{m}^{k-1}\right) h-\left(\zeta_{k}-\zeta_{k-1}\right)}{i \tau d}, 1 \leq k \leq N .
\end{gathered}
$$

Using the Cauchy-Schwartz inequality and triangle inequality, we get

$$
\begin{gathered}
\left|\frac{p_{k}+p_{k-1}}{2}\right| \\
\leq Q_{1}(q)\left(\left\|\left\{\frac{w_{m}^{k}-w_{m}^{k-1}}{\tau}\right\}_{m=1}^{M}\right\|_{L_{2 h}}+\left|\frac{\zeta_{k}-\zeta_{k-1}}{\tau}\right|\right)
\end{gathered}
$$

for all $1 \leq k \leq N$ and

$$
\begin{gathered}
\left\|\left\{\frac{p_{k}+p_{k-1}}{2}\right\}_{k=1}^{N}\right\|_{C[0, T]_{\tau}} \\
\leq Q_{1}(q)\left[\left\|\left\{\frac{1}{\tau}\left(w_{k}^{h}-w_{k-1}^{h}\right)\right\}_{k=1}^{N}\right\|_{C_{\tau}\left(L_{2 h}\right)}+\left\|\left\{\frac{\zeta_{k}-\zeta_{k-1}}{\tau}\right\}_{k=1}^{N}\right\|_{C[0, T]_{\tau}}\right] .
\end{gathered}
$$

Now, applying formulas (4) and (5), we obtain

$$
\frac{u_{n}^{k}-u_{n}^{k-1}}{\tau}=\frac{w_{n}^{k}-w_{n}^{k-1}}{\tau}-i \frac{p_{k}+p_{k-1}}{2} q_{n}
$$

and

$$
\begin{gathered}
\left\|\left\{\frac{1}{\tau}\left(u_{k}^{h}-u_{k-1}^{h}\right)\right\}_{k=1}^{N}\right\|_{C_{\tau}\left(L_{2 h}\right)} \leq\left\|\left\{\frac{1}{\tau}\left(w_{k}^{h}-w_{k-1}^{h}\right)\right\}_{k=1}^{N}\right\|_{C_{\tau}\left(L_{2 h}\right)} \\
+\left\|\left\{\frac{p_{k}+p_{k-1}}{2}\right\}_{k=1}^{N}\right\|_{C[0, T]_{\tau}}\left\|\left\{q_{n}\right\}_{n=1}^{M}\right\|_{L_{2 h}} .
\end{gathered}
$$

Then, the proof of Theorem 1 is based on the following theorem.

Theorem 2. For the solution of DS (6) the stability estimate is satisfied:

$$
\begin{gathered}
\left\|\left\{\frac{1}{\tau}\left(w_{k}^{h}-w_{k-1}^{h}\right)\right\}_{k=1}^{N}\right\|_{C_{\tau}\left(L_{2 h}\right)} \leq Q_{2}(a)\left[\left\|\varphi^{h}\right\|_{W_{2 h}^{2}}+\left|\zeta_{0}\right|\right. \\
\left.+\left\|f_{1}^{h}\right\|_{L_{2 h}}+\left\|\left\{\frac{1}{\tau}\left(f_{k}^{h}-f_{k-1}^{h}\right)\right\}_{k=2}^{N}\right\|\left\|_{C_{\tau\left(L_{2 h}\right)}}+\right\|\left\{\frac{\zeta_{k}-\zeta_{k-1}}{\tau}\right\}_{k=1}^{N} \|_{C[0, T]_{\tau}}\right] .
\end{gathered}
$$


Proof. We can write problem (6) as the abstract problem

$$
\left\{\begin{array}{l}
i \frac{w_{k}^{h}-w_{k-1}^{h}}{\tau}-\frac{A^{h}}{2}\left(w_{k}^{h}+w_{k-1}^{h}\right)=f_{k}^{h}+i A^{h} q^{h} \frac{\eta_{k}+\eta_{k-1}}{2} \\
t_{k}=k \tau, 1 \leq k \leq N, N \tau=T, w_{0}^{h}=\varphi^{h}
\end{array}\right.
$$

in $L_{2 h}$. Then,

$$
w_{k}^{h}=R^{k} \varphi^{h}-i \sum_{j=1}^{k} R^{k-j} C \tau\left(f_{j}^{h}+i A^{h} q^{h} \frac{\eta_{j}+\eta_{j-1}}{2}\right),
$$

where

$$
R=\left(I-i \tau \frac{A^{h}}{2}\right) C, C=\left(I+i \tau \frac{A^{h}}{2}\right)^{-1} .
$$

Taking the difference derivative and applying the Abel's formula, we get

$$
\begin{gathered}
\frac{w_{k}^{h}-w_{k-1}^{h}}{\tau}=-i R^{k-1} C A^{h} \varphi^{h}-i C\left(f_{1}^{h}+i A^{h} q^{h} \frac{\eta_{1}}{2}\right) \\
-i C \sum_{j=1}^{k} R^{k-j}\left(f_{j}^{h}-f_{j-1}^{h}\right)+C \sum_{j=1}^{k} R^{k-j} A^{h} q^{h} \frac{\eta_{j}-\eta_{j-1}}{2} .
\end{gathered}
$$

Applying formula (8) and estimates

$$
\|R\|_{H \longrightarrow H} \leq 1,\|C\|_{H \longrightarrow H} \leq 1
$$

we get

$$
\begin{gathered}
\left\|\frac{w_{k}^{h}-w_{k-1}^{h}}{\tau}\right\|_{L_{2 h}} \leq\left\|A_{h}^{x} \varphi^{h}\right\|_{H}+\left\|f_{1}^{h}\right\|_{L_{2 h}}+\sum_{j=2}^{k}\left\|f_{k}^{h}-f_{k-1}^{h}\right\|_{L_{2 h}} \\
+Q_{4}(q) \tau \sum_{j=2}^{k}\left[\left|\frac{\zeta_{j}-\zeta_{j-1}}{\tau}\right|+\left\|\frac{w_{j}^{h}-w_{j-1}^{h}}{\tau}\right\|_{L_{2 h}}\right]
\end{gathered}
$$

for any $k$. Then, applying the discrete analogy of the integral inequality, we get

$$
\begin{gathered}
\left\|\frac{w_{k}^{h}-w_{k-1}^{h}}{\tau}\right\|_{L_{2 h}} \\
\leq\left[\left\|A_{h}^{x} \varphi^{h}\right\|_{H}+\left\|f_{1}^{h}\right\|_{L_{2 h}}+\sum_{j=2}^{k}\left\|f_{k}^{h}-f_{k-1}^{h}\right\|_{L_{2 h}}+Q_{4}(q) \sum_{j=2}^{k}\left|\zeta_{j}-\zeta_{j-1}\right|\right] e^{\frac{Q_{4}(q) k \tau}{1-Q_{4}(q) \tau}}
\end{gathered}
$$

for any $k$. From that it follows (7).

\section{Numerical results}

We study the numerical solution of the identification problem

$$
\left\{\begin{array}{l}
i \frac{\partial u(t, x)}{\partial t}-\frac{\partial^{2} u(t, x)}{\partial x^{2}}+u(t, x)=p(t)(1+\sin 2 x) \\
+(3 \sin (2 x)-1) e^{i t}, x \in(0, \pi), t \in(0,1) \\
u(0, x)=1+\sin 2 x, x \in[0, \pi] \\
u(t, 0)=u(t, \pi), u_{x}(t, 0)=u_{x}(t, \pi) \\
\int_{0}^{\pi} u(t, x) d x=\pi e^{i t}, t \in[0,1]
\end{array}\right.
$$

for a one dimensional Schrodinger differential equation. The exact solution of this problem is $(u(t, x), p(t))=$ $=\left((1+\sin 2 x) e^{i t}, e^{i t}\right)$. Applying difference scheme (3) for problem (9), we get 


$$
\left\{\begin{array}{l}
i \frac{u_{n}^{k}-u_{n}^{k-1}}{\tau}-\frac{u_{n+1}^{k}-2 u_{n}^{k}+u_{n-1}^{k}}{2 h^{2}}-\frac{u_{n+1}^{k-1}-2 u_{n}^{k-1}+u_{n-1}^{k-1}}{2 h^{2}}+\frac{u_{n}^{k}+u_{n}^{k-1}}{2} \\
=\frac{p_{k+p_{k-1}}}{2}\left(1+\sin 2 x_{n}\right)+\left(3 \sin 2 x_{n}-1\right) e^{i\left(t_{k}-\frac{\tau}{2}\right)} \\
t_{k}=k \tau, x_{n}=n h, 1 \leq k \leq N, 1 \leq n \leq M-1 \\
u_{n}^{0}=1+\sin 2 x_{n}, 0 \leq n \leq M, M h=\pi, N \tau=1 \\
u_{M}^{k}=u_{0}^{k}, u_{M}^{k}-u_{M-1}^{k}=u_{1}^{k}-u_{0}^{k} \\
\sum_{m=1}^{M} u_{m}^{k} h=\pi e^{i t_{k}}, 0 \leq k \leq N .
\end{array}\right.
$$

The algorithm for obtaining the solution $\left\{\left\{u_{n}^{k}\right\}_{0}^{N}\right\}_{0}^{M}$ and $\left\{p_{k}\right\}_{1}^{N}$ of DS (10) contains three steps. We introduce $\eta_{k}$ by the formula

$$
\eta_{k}=\frac{p_{0}+p_{k}}{2} \tau+\sum_{m=1}^{k-1} p_{m} \tau, k \in \overline{1, N}, \eta_{0}=0
$$

Then,

$$
\begin{gathered}
\frac{p_{k}+p_{k-1}}{2}=\frac{\eta_{k}-\eta_{k-1}}{\tau}, k \in \overline{1, N} \\
u_{n}^{k}=w_{n}^{k}-i \eta_{k}\left(1+\sin 2 x_{n}\right), k \in \overline{0, N}, n \in \overline{0, M} .
\end{gathered}
$$

Here $w_{n}^{k}$ is the solution of the DS

$$
\left\{\begin{array}{l}
i \frac{w_{n}^{k}-w_{n}^{k-1}}{\tau}-\frac{w_{n+1}^{k}-2 w_{n}^{k}+w_{n-1}^{k}}{2 h^{2}}-\frac{w_{n+1}^{k-1}-2 w_{n}^{k-1}+w_{n-1}^{k-1}}{2 h^{2}}+\frac{w_{n}^{k}+w_{n}^{k-1}}{2} \\
-z_{n} h \sum_{k=1}^{M} w_{m}^{k}-z_{n} h \sum_{k=1}^{M} w_{m}^{k-1}=z_{n} \pi\left(e^{i t_{k}}+e^{i t_{k-1}}\right) \\
+\left(3 \sin 2 x_{n}-1\right) e^{i\left(t_{k}-\frac{\tau}{2}\right)}, k \in \overline{1}, N, n \in \overline{1, M-1} \\
w_{n}^{0}=1+\sin 2 x_{n}, n \in \overline{1, M-1} \\
w_{M}^{k}=w_{0}^{k}, w_{M}^{k}-w_{M-1}^{k}=w_{1}^{k}-w_{0}^{k}
\end{array}\right.
$$

where

$$
z_{n}=\frac{1}{\pi+d h}\left[\sin 2 x_{n}\left(\frac{1-\cos 2 h}{h^{2}}-\frac{1}{2}\right)-\frac{1}{2}\right], n \in \overline{1, M-1} .
$$

Using the discrete analogy of integral condition in (14), we get

$$
\eta_{k}=\frac{\sum_{m=1}^{M} w_{m}^{k} h-\pi e^{i t_{k}}}{i(\pi+d h)}, d=\sum_{m=1}^{M} \sin 2 x_{m}, k \in \overline{1, N}
$$

Step 1: According to DS (10), we obtain $\left\{\left\{w_{n}^{k}\right\}_{0}^{N}\right\}_{0}^{M}$.

We can write (14) as difference equation with matrix coefficients

$$
A w^{k}+B w^{k-1}=\varphi^{k}, 1 \leq k \leq N
$$

for any $k$. Here $\mathrm{A}$ and $\mathrm{B}$ are $(M+1) \mathrm{x}(M+1)$ square matrices and $\varphi$ is $(M+1) \mathrm{x} 1$ colomn matrix

$$
\begin{gathered}
A=\left[\begin{array}{cccccc}
1 & 0 & 0 & \cdot & 0 & -1 \\
a & b-h z_{1} & -h z_{1} & \cdot & -h z_{1} & -h z_{1} \\
0 & a-h z_{2} & a-h z_{2} & \cdot & -h z_{2} & -h z_{2} \\
\cdot & \cdot & \cdot & \cdot & \cdot & \cdot \\
0 & -h z_{M-1} & -h z_{M-1} & \cdot & b-h z_{M-1} & a-h z_{M-1} \\
1 & -1 & 0 & \cdot & -1 & 1
\end{array}\right]_{(M+1) \times(M+1)} \\
B=\left[\begin{array}{cccccc}
0 & 0 & 0 & \cdot & 0 & 0 \\
a & a-h z_{1} & c-h z_{1} & \cdot & -h z_{1} & 0 \\
0 & a-h z_{2} & c-h z_{2} & \cdot & -h z_{2} & 0 \\
\cdot & \cdot & \cdot & \cdot & \cdot & \cdot \\
0 & -h z_{M-1} & -h z_{M-1} & \cdot & c-h z_{M-1} & a \\
0 & 0 & 0 & \cdot & 0 & 0
\end{array}\right]_{(M+1) \times(M+1)},
\end{gathered}
$$




$$
\begin{aligned}
& a=-\frac{1}{2 h^{2}}, b=\frac{i}{\tau}+\frac{1}{h^{2}}+\frac{1}{2}, c=-\frac{i}{\tau}+\frac{1}{h^{2}}+\frac{1}{2}, \\
& \varphi_{n}^{k}=\left[\begin{array}{c}
0 \\
\varphi_{1}^{k} \\
\cdot \\
\varphi_{M-1}^{k} \\
0
\end{array}\right]_{(M+1) \times 1}, w^{k}=\left[\begin{array}{c}
w_{0}^{k} \\
w_{1}^{k} \\
\cdot \\
w_{M-1}^{k} \\
w_{M}^{k}
\end{array}\right]_{(M+1) \times 1}, \\
& w^{0}=\left[\begin{array}{c}
1+\sin 2 x_{0} \\
1+\sin 2 x_{1} \\
\cdot \\
1+\sin 2 x_{M-1} \\
1+\sin 2 x_{M}
\end{array}\right]_{(M+1) \times 1} \\
& \varphi_{n}^{k}=z_{n} \pi\left(e^{i t_{k}}+e^{i t_{k-1}}\right)+\left(3 \sin 2 x_{n}-1\right) e^{i\left(t_{k}-\tau / 2\right)}, 1 \leq k \leq N .
\end{aligned}
$$

Therefore

$$
w^{k}=\operatorname{inv}(A)\left(\varphi^{k}-B w^{k-1}\right)
$$

Step 2: We will find $\left\{\eta_{k}\right\}_{0}^{N},\left\{\frac{p_{k}+p_{k-1}}{2}\right\}_{1}^{N}$ by formulas (12) and (15).

Step 3: We will find $\left\{\left\{u_{n}^{k}\right\}_{0}^{N}\right\}_{0}^{M}$ by formulas (11) and (13). The errors are computed by

$$
\begin{gathered}
E_{u}=\max _{k \in \overline{0, N}}\left(\sum_{n=0}^{M}\left|u\left(t_{k}, x_{n}\right)-u_{n}^{k}\right|^{2} h\right)^{\frac{1}{2}}, \\
E_{p}=\max _{k \in \overline{1, N}}\left|p\left(t_{k}\right)-\frac{p_{k}+p_{k-1}}{2}\right| .
\end{gathered}
$$

Numerical solutions of problem $(9) u(t, x)$ at $\left(t_{k}, x_{n}\right)$ is $u_{n}^{k}$ and of $p(t)$ at $t_{k}$ is $\frac{p_{k}+p_{k-1}}{2}$. The result of numerical experience for problem (9) is provided in Table 1.

Error Analysis

\begin{tabular}{|l|l|l|l|}
\hline Error & $M=N=20$ & $M=N=40$ & $M=N=80$ \\
\hline$E_{p}$ & 0.0002 & 0.00005 & 0.00001 \\
\hline$E_{u}$ & 0.017 & 0.0043 & 0.0011 \\
\hline
\end{tabular}

\section{Conclusion}

In this article the SIP for the one-dimensional SE with non-local boundary conditions is studied. A second order of accuracy Crank-Nicolson difference scheme for the numerical solution of the differential problem is presented. Theorem on stability of this difference scheme is established. The numerical results are given. Finally, this operator approach permits us to investigate one-dimensional SE with classical boundary conditions.

\section{Acknowledgements}

We would like to thank the following institutions for their support. The publication has been prepared with the support of the "RUDN University Program 5-100". This research has been funded by the Science Committee of the Ministry of Education and Science of the Republic of Kazakhstan (Grant No. AP08855352). 


\section{References}

1 Prilepko D.G. Methods for Solving Inverse Problems in Mathematical Physics / A.I. Prilepko, D.G. Orlovsky, I.A.Vasin. - Dekker Incorporated Marcel, 1987.

2 Kabanikhin S.I. Methods for solving dynamic inverse problems for hyperbolic equations / S.I. Kabanikhin // Journal Inverse Ill-Posed Problem. - 2014. - 12. - P. 493-517.

3 Belov Yu.Ya. Inverse problems for partial differential equations / Yu.Ya. Belov // Inverse and Ill-posed Problems Series-VSP, 2002.

4 Gryazin Y.A. Imaging the diffusion coefficient in a parabolic inverse problem in optical tomography $/$ Y.A. Gryazin, M.V. Klibanov, T.R. Lucas // Inverse Problems. - 1999. - 15. - No.2. - P. 373-397.

5 Ashyralyyev C. High order of accuracy difference schemes for the inverse elliptic problem with Dirichlet condition / C. Ashyralyyev // Boundary Value Problems. - 2014. - 5. - P. 1-23.

6 Ashyralyyev C. High order approximation of the inverse elliptic problem with Dirichlet-Neumann conditions / C. Ashyralyyev // Filomat. - 2014. - 28. - No. 5. - P. 947-962.

7 Ashyralyev A. On the problem of determining the parameter of an elliptic equation in a Banach space / A. Ashyralyev, C. Ashyralyyev // Nonlinear Anal. Model. Control. - 2014. - 19. - No. 3. - P. 350-366.

8 Ashyralyev A. Determination of a control parameter for the difference Schrödinger equation / A. Ashyralyev, M. Urun // Abstract and Applied Analysis. - 2013. - ID 548201. — 8 p.

9 Kostin A.B. The inverse problem of recovering the source in a parabolic equation under a condition of nonlocal observation / A.B. Kostin // Matematicheskii Sbornik Russian. - 2013. - 204. - No. 10. - P. 1391-1434.

10 Ashyralyev A. On a problem of determining the parameter of a parabolic equation / A. Ashyralyev // Ukrainian Mathematical Journal. - 2011. - 62. - No. 9. - P. 1397-1408.

11 Choulli M. Generic well-posedness of a linear inverse parabolic problem with diffusion parameter / M. Choulli, M. Yamamoto // Journal of Inverse and III-posed Problems. - 1999. - 7. — No. 3. - P. 241254.

12 Ashyralyev A. Source identification problems for hyperbolic differential and difference equations / A. Ashyralyev, F. Emharab // Journal of Inverse and Ill-posed Problems. - 2019. - 27. - No. 3. - P. 301-315.

13 Saitoh S. Reverse convolution inequalities and applications to inverse heat source problems / S. Saitoh, V.K. Tuan, M. Yamamoto // Journal of Inequalities in Pure and Applied Mathematics. — 2002. - 3. No. 5. - Article 80. - 11 p.

14 Ivanchov N.I. On the determination of unknown source in the heat equation with nonlocal boundary conditions / N.I. Ivanchov // Ukrainian Mathematical Journal. - 1995. - 47. - No. 10. - P. $1647-1652$.

15 Borukhov V.T. Numerical solution of the inverse problem of reconstructing a distributed right-hand side of a parabolic equation / V.T. Borukhov, P.N. Vabishchevich // Computer Physics Communications. 2000. - 126. - P. 32-36.

16 Ashyralyev A. Well-posedness of the right-hand side identification problem for a parabolic equation / A. Ashyralyev, A.S. Erdogan // Ukrainian Mathematical Journal. - 2014. - 66. - No. 2. - P. $165-177$.

17 Samarskii A.A. Numerical Methods for Solving Inverse Problems of Mathematical Physics / A.A. Samarskii, P.N. Vabishchevich // Inverse and Ill-posed Problems Series-Berlin, Walter de Gruyter, New York, 2007.

18 Blasio G. Di. Identification problems for parabolic delay differential equations with measurement on the boundary / G. Di. Blasio, A. Lorenzi // Journal of Inverse and Ill-Posed Problems. — 2007. - 15. No. 7. - P. 709-734.

19 Ashyralyev A. On source identification problem for a delay parabolic equation / A. Ashyralyev, D. Agirseven // Nonlinear Analysis: Modelling and Control. - 2014. - 19. - No. 3. - P. 335-349.

20 Orazov I. On a class of problems of determining the temperature and density of heat sources given initial and final temperature / I. Orazov, M.A. Sadybekov // Siberian Mathematical Journal. — 2012. — 53. P. $146-151$.

21 Ashyralyev A. Numerical solution of a source identification problem / A. Ashyralyev, A. S. Er- dogan, A.U. Sazaklioglu // Journal of Inverse and Ill-posed Problems. - 2019. - 27. - No. 4. - P. 457-468.

22 Aliev F. A method to determine the coefficient of hytdrolic resistance in different areas of pump-compressor piper / F. Aliev, N.A. Ismailov, H. Haciyev, M.F. Guliev // TW MS Journal of Pure and Applied Mathematics. - 2016. - 7. - No. 2. - P. 211-217. 
23 Aliev F.A. Algorithm for calculating the parameters of formation of gas-liquid mixture in the shoe of gas lift well / F.A. Aliev, N.A. Ismailov, A.A. Namazov, M.F. Rajabov // Applied and Computational Mathematics. - 2016. - 15. - No. 3. - P. 370-376.

24 Hicdurmaz B. Finite difference schemes for time-fractional Schrödinger equations via fractional linear multi step method / B. Hicdurmaz // International Journal of Computer Mathematics. - 2020. DOI:10.108 0/00207160/1834088.

25 Ashyralyev A. Time-Dependent Source Identification Problem for the Schrödinger equation with Nonlocal Boundary Conditions / A. Ashyralyev, M. Urun // AIP Conference Proceedings. — 2019. — 2183. 070016.

26 Hidurmaz B. Initial boundary value problems for fractional Schrödinger differential equations / PhD Thesis, Gebze Technical University, Kocaeli, 2015.

27 Sirma A. Nonlocal boundary value problems for Schrödinger equation / PhD Thesis, Gebze Institute of Technology, Kocaeli, 2007.

28 Sirma A. Rothe-Maruyama difference scheme for the stochastic Schrodinger equation / A. Sirma // International Journal of Applied Mathematics. - 2021. - 34. - No. 2.

29 Sadybekov M. A. Stable difference scheme for a nonlocal boundary value heat conduction problem / M.A. Sadybekov // e-Journal of Analysis and Applied Mathematics. - 2018. - 2018. - No. 1. - P. 1-10.

30 Agirseven D. On the stability of the Schrödinger equation with time delay / D. Agirseven // Filomat. 2018. - 32. - No. 3. - P. 759-766.

31 Hicdurmaz B. Multidimensional problems for general coupled systems of time-space fractional Schrödinger equations / B. Hicdurmaz // Journal of Coupled Systems and Multiscale Dynamics. - 2020. - 6. - No. 2. - P. 147-153.

32 Hicdurmaz B. Finite difference method for a nonlinear fractional Schrödinger equation with Neumann condition / B. Hicdurmaz // e-Journal of Analysis and Applied Mathematics. - 2020. — 2020. - No. 1. - P. 67-80.

33 Ashyralyev A. Time-dependent source identification Schrödinger type problem / A. Ashyralyev, M. Urun // International Journal of Applied Mathematics. - 2021. - 34. - No. 2.

\author{
А. Ашыралыев ${ }^{1-3}$, М. Урун ${ }^{1,4}$ \\ ${ }^{1}$ Таяу Шывыс университеті, Никосия, Түркия; \\ ${ }^{2}$ Ресей халықтар достывы университеті, Мәскеу, Ресей; \\ ${ }^{3}$ Математика және математикалық, модельдеу институты, Алматы, Қазақстан; \\ ${ }^{4}$ Галатасарай университеті, Стамбул, Түркия
}

\title{
Дереккөзді идентификациялау бейстационарлы есебі үшін Кранк-Николсонның айырымдық схемасы туралы
}

\begin{abstract}
Мақалада бейлокалды шекаралық шарттары бар Шредингердің бір өлшемді теңдеуі үшін дереккөзді идентификациялау есебі қарастырылды. Дифференциалдық есепті сандық шешуге арналған екінші дәлдік ретті Кранк-Николсонның айырымдық схемасы ұсынылған. Осы айырымдық схеманың шешімінің тұрақтылығын бағалаулары дәлелденді және сандық нәтижелер келтірілген.
\end{abstract}

Kiлm сөздер: идентификациялау мәселесі, Шредингер теңдеуі, айырымдық схемасы, Кранка-Николсон, тұрақтылық. 


\author{
А. Ашыралыев ${ }^{1-3}$, М. Урун ${ }^{1,4}$ \\ ${ }^{1}$ Ближневосточный университет, Никосия, Турция; \\ ${ }^{2}$ Российский университет дружбъ народов, Москва, Россия; \\ ${ }^{3}$ Институт математики и математического моделирования, Алмать, Казахстан; \\ ${ }^{4}$ Галатасарайский университет, Стамбул, Туриия
}

\title{
О разностной схеме Кранка-Николсона для нестационарной задачи идентификации источника
}

В статье рассмотрена задача идентификации источника для одномерного уравнения Шредингера с нелокальными граничными условиями. Представлена разностная схема Кранка-Николсона второго порядка точности для численного решения дифференциальной задачи. Доказаны оценки устойчивости решения этой разностной схемы, и приведены численные результаты.

Ключевые слова: проблема идентификации, уравнение Шредингера, разностная схема Кранка-Николсона, устойчивость.

\section{References}

1 Prilepko, D.G., Orlovsky, D.G., \& Vasin, I.A. (1987). Methods for Solving Inverse Problems in Mathematical Physics. Dekker Incorporated Marcel.

2 Kabanikhin, S.I. (2014). Methods for solving dynamic inverse problems for hyperbolic equations. Journal Inverse Ill-Posed Problem, 12, 493-517.

3 Belov, Yu.Ya. (2002). Inverse problems for partial differential equations. Inverse and Ill-posed Problems Series, VSP.

4 Gryazin, Y.A., Klibanov, M.V., \& Lucas, T.R. (1999). Imaging the diffusion coefficient in a parabolic inverse problem in optical tomography. Inverse Problems, 15(2), 373-397.

5 Ashyralyyev, C. (2014). High order of accuracy difference schemes for the inverse elliptic problem with Dirichlet condition. Boundary Value Problem, 5, 1-23.

6 Ashyralyyev, C. (2014). High order approximation of the inverse elliptic problem with Dirichlet-Neumann conditions. Filomat, 28(5), 947-962.

7 Ashyralyev, A., \& Ashyralyyev, C. (2014). On the problem of determining the parameter of an elliptic equation in a Banach space. Nonlinear Anal. Model. Control, 19(3), 350-366.

8 Ashyralyev, A., \& Urun, M. (2013). Determination of a control parameter for the difference Schrödinger equation. Abstract and Applied Analysis, ID 548201, 1-8.

9 Kostin, A.B. (2013). The inverse problem of recovering the source in a parabolic equation under a condition of nonlocal observation. Matematicheskii Sbornik Russian, 204(10), 1391-1434.

10 Ashyralyev, A. (2010). On a problem of determining the parameter of a parabolic equation. Ukrainian Mathematical Journal, 62 (9), 1397-1408.

11 Choulli, M., \& Yamamoto, M. (1999). Generic well-posedness of a linear inverse parabolic problem with diffusion parameter. Journal of Inverse and III-posed Problems, 7(3), 241-254.

12 Ashyralyev, A., \& Emharab, F. (2019). Source identification problems for hyperbolic differential and difference equations. Journal of Inverse and Ill-posed Problems, 27(3), 301-315.

13 Saitoh, S., Tuan, V.K., \& Yamamoto, M. (2002). Reverse convolution inequalities and applications to inverse heat source problems. Journal of Inequalities in Pure and Applied Mathematics, 3(5), ID 80, $1-11$.

14 Ivanchov, N.I. (1995). On the determination of unknown source in the heat equation with nonlocal boundary conditions. Ukrainian Mathematical Journal, 47(10), 1647-1652.

15 Borukhov, V.T., \& Vabishchevich, P.N. (2000). Numerical solution of the inverse problem of reconstructing a distributed right-hand side of a parabolic equation. Computer Physics Communications, 126, 32-36.

16 Ashyralyev, A., \& Erdogan, A.S. (2014). Well-posedness of the right-hand side identification problem for a parabolic equation. Ukrainian Mathematical Journal, 66(2), 165-177. 
17 Samarskii, A.A., \& Vabishchevich, P.N. (2007). Numerical Methods for Solving Inverse Problems of Mathematical Physics. Inverse and Ill-posed Problems Series, Walter de Gruyter, Berlin, New York .

18 Blasio, G. Di., \& Lorenzi, A. (2007). Identification problems for parabolic delay differential equations with measurement on the boundary. Journal of Inverse and Ill-Posed Problems, 15(7), 709-734.

19 Ashyralyev, A., \& Agirseven, D. (2014). On source identification problem for a delay parabolic equation. Nonlinear Analysis Modelling and Control, 19(3), 335-349.

20 Orazov, I., \& Sadybekov, M. A. (2012). On a class of problems of determining the temperature and density of heat sources given initial and final temperature. Siberian Mathematical Journal, 53, 146-151.

21 Ashyralyev, A., Erdogan, A. S., \& Sazaklioglu, A. U. (2019). Numerical solution of a source identification problem. Journal of Inverse and Ill-posed Problems, 27(4), 457-468.

22 Aliev, F.A., Ismailov, N.A., Haciyev, H., \& Guliev, M.F. (2016). Methot to determine the coefficient of hytdrolic resistance in different areas of pump-compressor piper. TWMS Journal of Pure and Applied Mathematics, 7(2), 211-217.

23 Aliev, F.A., Ismailov, N.A., Namazov, A.A., \& Rajabov, M.F. (2016). Algorithm for calculating the parameters of formation of gas-liquid mixture in the shoe of gas lift well. Applied and Computational Mathematics, $15(3), 370-376$.

24 Hicdurmaz, B. (2020). Finite difference schemes for time-fractional Schrödinger equations via fractional linear multi step method. International Journal of Computer Mathematics. DOI:10.1080/00207160/1834088.

25 Ashyralyev, A.,\& Urun, M. (2019). Time-dependent source identification problem for the Schrödinger equation with nonlocal boundary conditions. AIP Conference Proceedings, 2183, 070016.

26 Hidurmaz, B. (2015). Initial Boundary Value Problems for Fractional Schrödinger Differential Equations. $\mathrm{PhD}$ Thesis, Gebze Technical University, Kocaeli.

27 Sirma, A. (2007). Nonlocal Boundary Value Problems for Schrödinger Equation. PhD Thesis, Gebze Institute of Technology, Kocaeli.

28 Sirma, A. (2021). Rothe-Maruyama difference scheme for the stochastic Schrodinger equation. International Journal of Applied Mathematics, $34(2)$.

29 Sadybekov, M. A. (2018). Stable difference scheme for a nonlocal boundary value heat conduction problem. e-Journal of Analysis and Applied Mathematics, 2018(1), 1-10.

30 Agirseven, D. (2018). On the stability of the Schrödinger equation with time delay. Filomat, 32(3), 759-766.

31 Hicdurmaz, B. (2020). Multidimensional problems for general coupled systems of time-space fractional Schrödinger equations. Journal of Coupled Systems and Multiscale Dynamics, 6(2), 147-153.

32 Hicdurmaz, B. (2020). Finite difference method for a nonlinear fractional Schrödinger equation with Neumann condition. e-Journal of Analysis and Applied Mathematics, 2020(1), 67-80.

33 Ashyralyev, A., \& Urun, M. (2021). Time-dependent source identification Schrödinger type problem. International Journal of Applied Mathematics, $34(2)$. 